\title{
Ruyer and Simondon on Technological Inventiveness and Form Outlasting lts Medium
}

\section{Philippe Gagnon Centre Théologique de Meylan-Grenoble}

\begin{abstract}
A summary is provided of Ruyer's important contribution, a reversal from some conclusions held in his secondary doctoral dissertation, about the limits inherent in technological progress, and an attempt is made to show the coherence of this position with Ruyer's metaphysics. Simondon's response is also presented, and subsequently analysed especially as it culminates in a concept of concretisations. As Simondon indicated, and with a displacement in Ruyer's limiting framework on unconditional growth, we end up searching for what represents the category of the ultimate for those two philosophers of the cyberworld.
\end{abstract}

Keywords: technological determinism, Cournot, Ruyer, Simondon, industrial development, information

\section{Introduction: Cournot Philosophising on the Conquest of the World and the Stringency of Social Planning}

When philosopher of science Raymond Ruyer (1902-87) prepared his primary and secondary doctoral dissertations for the Doctorat ès lettres at the École normale supérieure, he chose for the first to try to identify the element or ingredient of reality that could account for reality's ultimate knowability, and found it in the notion of 'structure', in both a geometric and physical sense. This philosophy could not further proceed in light of what was discovered when he was interned at an

Deleuze Studies 11.4 (2017): 538-554

DOI: $10.3366 /$ dls.2017.0284

(C) Edinburgh University Press www.euppublishing.com/dls 
Offizierslager during World War II, in the company of some of France's best scholars - among whom were embryologist E. Wolff and botanist A. Moyse. Ruyer spent more time then considering things that would not fit so well in his overall interpretive scheme, such as morphic development in biology.

What is interesting for our purposes is to consider how he chose for his secondary dissertation the question of humankind's future according to Antoine A. Cournot (1801-77). This was an attempt to implement in a subject charged with much philosophical significance the key insight into a mechanical ordering of the interactions of multiple elements. In so doing, Ruyer met Cournot's pioneering attempts to try to map geometrical insights onto the question of how the steering over a social order was possible, when 'free life' had started to exert its call, and had produced multifarious shapes and structural relationships (see Cournot 1875; Liard 1877: 112-15).

When very many individuals do very many things, one gets close to the etymological significance of complexity, 'a great many objects and a great number of figures'. Cournot's proposal in front of model-building and societal becoming was to think that a force, an element driving the tendency to reproduction, accounted for genealogical relationships and the perpetuation of life, but to also think that rational order was inimical to it. Engineering uses simplified models of reality and always in a sense ends up forcing reality into these models. Cournot theorised that the living force, with its charge of emotional relatedness, would become less important, and that with rational planning and ordering taking over, the law of statistical averaging would come to win, and produce a world in which wars, heroism and antagonisms that drive complexity would dwindle and die (see Ruyer 1930: 15-16).

\section{Ruyer's View of Technology's Inherent Dynamic}

In his article on technology's inherent drive to progress (Ruyer 1958: 412-23), which was the occasion for a response by G. de Santillana (1958), Ruyer first exposes Cournot's insight that societies are made from two different substrata, that they are a mix of elements like the Minotaur. Ruyer recalls how Cournot distinguished, in his ontology, between three elements: (1) the material; (2) the living-which as a realm cannot be understood by us rationally; and (3) the rational. Rationality is a power that arises in human beings but it is also a project requiring an anticipated completion, and we discover sometimes with astonishment that it is endowed with an internal determinism that will lead to its own 
entanglement in itself. It places human beings outside of life, and as such the historical outlook allows the reasonable and the utilitarian to win over the poetic and the heroic (Cournot 1861: 16, 170, 222-40). Not only will those two elements bring about the end of those instincts which do not follow from the use of reason, but the temporality of populations that are not rationally organised as civilisations will not possess true historical elements. History takes over when thinking and planning beings discern reference points, as part of the work of rationality.

The German philosopher and literary figure, Ernst Jünger (1895-1998), like Cournot, admired in many native peoples the activities that determine time, as opposed to those activities, in their abstract nature, that universalise time, sending one to work and calling one back home (Jünger [1959](1994): 20-2). In these cultures, time is deemed ahistorical. A people that have reached a high level of rationally organised civilisatory effort will have no history, Jünger says. The time in-between these two periods of 'dream' so to speak, the time of history, has been a time of war and conquest, the playground for a certain irrationality.

Cournot, like Jünger, possessed a significant vitalist component within his thought. He believed in a principle of animation, a force that gave life to the social fabric, but one that could also choose to disappear from it, and leave it to its own destiny or fate, somewhat like the biblical God who, faced with human creatures' rebellion, lets them exploit their own resources, which, for example, leads to the confusion in language around the Tower of Babel (Gen. 11). Ruyer considers, drawing on the then prevalent structuralism, that primitive societies were not calculated such as ours are, and wages that our own living civilised societies, instead of being driven into mechanisation of relationships, will reconstitute themselves as would a living being, as a biological organism regenerating or regrowing its body, such that the periods of social physics of the 'Quetelet' style (2013: 96-108) will serve to prepare new becomings. ${ }^{1}$

Ruyer considers that Cournot's most solid thesis is the one that deals with technology as an external prolongation of the internal technology of life. Cournot imagined a law of arithmetic progression but irreversible summation, in other words a progression by accretion. For Ruyer, it remains to be seen what the nature of this progression is. Is it exponential? Is it factorial? Provocatively, Ruyer asserts that the march of progress in the technical sense will stop, that it will get exhausted: we cannot continue following the accelerated curve. This is not for him an extrapolation of that same seemingly linear function, it is rather the impossibility of any extrapolation as far as transformation of available 
resources is concerned, because of scarcity and the vanishing of raw materials, which entails that inventions will have to be limited.

Ruyer makes it plain that there are two laws that come to clash: first, the law of conservation of matter-energy; and second, the free multiplication of form or idea. The second law contains, in a certain sense, all his philosophy. The cost of information in a physical support, as L. Brillouin established in a famous analysis, is not zero, but it also has no common measure with the cost of industrial realisations and projects. It costs almost nothing for nature to multiply germ cells, and even fertilised eggs, but nature cannot drive and nurture to fully-fledged form all those eggs, because what is missing is energetic resources in the form of foodstuffs. In the same way, material and energetic capitals' availability limit their progress, just as the challenge of subsisting limits the possibilities of reproduction.

When the industrial system becomes one with the social system, they eventually come to control technical mutations and manifest a tendency to self-conserve and resist the forces of change. One could think that the line of acceleration of progress would keep going with the conquering effort divided between giant conglomerates, but we easily understand that in the context of large social planning, which seems to imply a progress that is accelerated, there is in fact the dawn of a social crystallisation.

Ruyer considers that even if one were to go wrong in foreseeing how accelerated progress would have to slow down, it is impossible to go wrong in predicting the fact that the acceleration of industrialisation will end. For him, Cournot judged wrongly when he spoke of a summation of continued accretion of technical progress; in fact, it is certainly accelerated, but then it breaks down and stops. Continued growth, even outpacing forecasts, that comes to a sudden halt, is best captured by the sigmoid function (see Figure 1).

If one plots along the abscissa the independent variable of time, and on the ordinate the speed of, for example, the computer processor, where Moore's law as initially stated tells us that that speed will double every twelve months, one sees that continued growth as predicted must come to a halt. R. Kurzweil, author of The Age of Spiritual Machines (1998: 254-5), states that a grander law seems to apply according to which, even if refinements to an innovation were to begin to run up against physical and technical constraints, a new paradigm would emerge and continue the trend. Behind Kurzweil's rhetoric around the rarity of organisation and its inevitability, which he ties to the inevitability of the build-up of complexity, is an instanciation of the 'principle of plenitude'. 


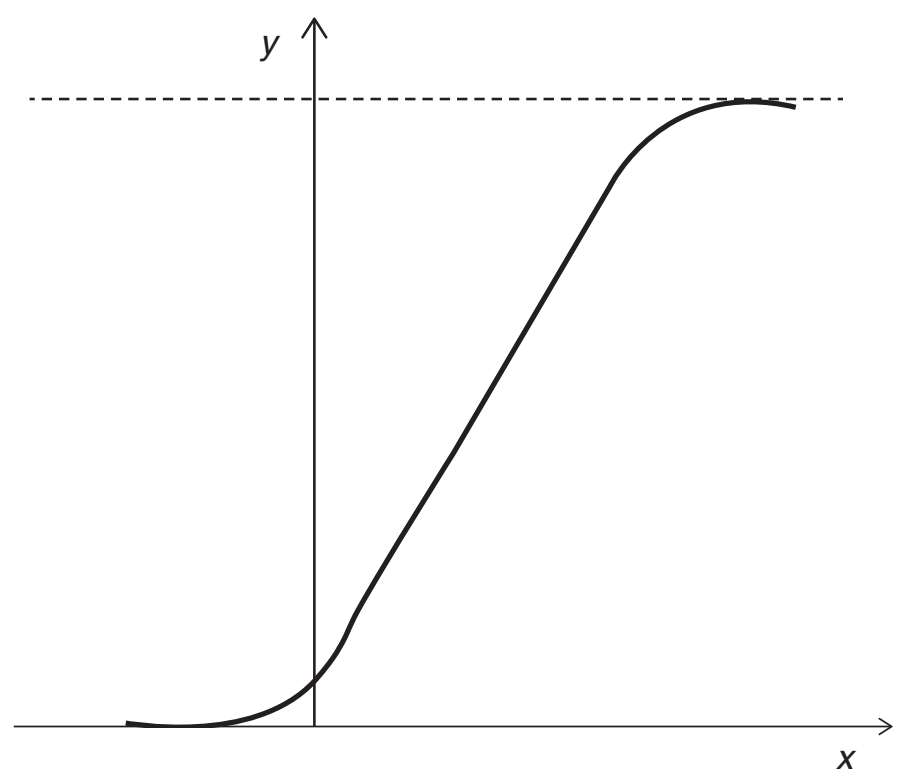

Figure 1. Sigmoid function.

Even to those, such as K. Shapiro, who have objected the far-away nature of nanobots, or the limitations of the reorganisation powers of the brain, or even the absence of any superiority in computers' capacity to solve problems contrasted to ours save for speed, Kurzweil could always reassert his law of 'rare and plentiful' since it is based on a tacit attribution of powers to ratchet up when progress encounters obstacles (Shapiro 2005: 67). As I. Hutchinson pointed out, this leaves out the fact that we have in such a case two intertwined, and profoundly different, dynamics, with successes of the digital tested on analogical neural networks (Hutchinson 2000: 261).

One more point is worth expounding on. We have seen how Cournot thought in terms of 'realms', and this is precisely the cosmological outlook that Ruyer has come to reject, inviting us instead to think in terms of fibrous lines of individualised development, with lateral openness for colonisations and thus further transformations (Ruyer 1968: 189). For Ruyer, what is fundamental is that developing beings aim at a value, which is also participation in a developmental scheme. When this is contrasted to Cournot's realms presented earlier, the idea of a passage from the vital/organic to the mechanical, the mathematicised and the geometrised must as a thesis be discarded, since a true form 
cannot be destroyed in any statistical scattering, as it is, in Ruyerian language, a condition of possibility of such statistical existence (Ruyer 1970a: 232-4).

\section{Ruyer's Metaphysically Grounded Guiding Principles: The Place of 'Thematism'}

One of the most striking traits of Ruyer's metaphysics is the positioning of this ultimate vital force within an act of existence through a vertical harmonisation with a 'theme', such that rationality is not primarily about problems ordered by language and logic, but is about the capacity to achieve organic togetherness.

Therefore, concerning the development of biological organisms, the laying off of parts and appendages, the re-entering into the theme of various parts, is not to be understood as the setting of oneself on tracks that would conduce any reality to a final obedience of rationality to some mindless physical force. Rather, there is a homogeneous order among the parts, one that can be retrieved behind the orientation of any parts' velocity that is held in a common direction when, say, for example, a watermill is propelled into a structured order, which establishes that the watermill itself would never be repaired and maintained, nor would the body of the mill operator be produced in the first place, if all there ever was is such a process of homogeneous ordering (Ruyer 1968: 118-22). As Whitehead saw this, it would be akin to claiming that the process responsible for the incessant ebb and flow of water waves on the shore could just as well have built up the ship (Whitehead [1929] 1958: 13-14).

\section{Simondon on the Stages in Technological Development and the Conditions for Concretisation}

Choosing to write, a year later, a response to Ruyer's presentation, Gilbert Simondon (1924-89) did not at first consider Ruyer's 'inverted' fatalism, or deterministic corrected vitalism, as a philosophy that might seriously influence him (Simondon 2010: 231). For Simondon, it is indeed possible to see technological development as taking a road leading to a form of rationalist alienation from vital human values, but this only takes place because the technological object is set against an environment that is not homogeneously changing with it.

Simondon pays much attention to the series of possible objective concretisations, and notes how we tend to identify technical progress 
with human progress. How do we know that this progress, exhausting the means and materials of implementation of ideas born in its wake, is not going to be superseded by yet another form of progress?

Objective concretisations have kept reappearing, and human beings have made themselves their promoters. In every cycle of progress, the human element forms a system with what is being concretised, but many latent possibilities are always left out at the same time. Analysing things alongside a tripartite division:

humanity/language $\Rightarrow$ humanity/religion $\Rightarrow$ humanity/technology,

Simondon points out how the centre of systematisation displaces itself: it starts by being between human beings and objective concretisation, and then it is objective concretisation which becomes the whole system. When human beings excentre themselves, concretisations become mechanised. This same 'model inversion' has been addressed by Ruyer, pointing out that cybernetics aims at reproducing efficiently and behaviouristically the action of organs whose finality is swapped into machine-language programming, except that the macro-structures thus imitated were themselves kept in being by micro-domains working at the furtherance of their form.

For Simondon, technology alone is absolutely universalisable; there is a chance that rationality and alienation may be less impactful visà-vis technology than they would vis-à-vis language and religion. This presupposes that human beings are able to become homogeneous with technical objects. The non-alienation threshold would be met when the human agent intervenes in technology as both operator and object of operation (Simondon 2010: 233). Technology could create the onset of a non-sigmoid development if it replaced completely the activity of language and religion. Thus, what Simondon calls for is nothing short of an axiological heightening of the technological aspect rendered capable of expressing sacredness, which means a complete reconciliation of self and sacred space, a prerogative of a spiritual or angelic being, as traditional religious terminology would have it.

One can predict that technical progress will not always have the explosive aspect that it manifests in the domain of objective-rational concretisation: 'It would be wrong to confuse technical progress, of value to vast groups of human beings, with the exceptional results achieved in the specialist milieu of scientific technology' (Simondon 2010: 234). The appearance of an explosive progress is most often due to a nonharmonised introduction of a technical object in an environment which is not otherwise modified alongside it. Progress is explosive when in its 
very inception it is scattered (éclaté). For technical progress to be selfregulative, it has to be a wholesome progress, with all domains of activity using communication techniques with each other; then we will have an organic progress in relation to the evolution of man (see Simondon [1958] 1989: 70).

Simondon therefore considers that Ruyer does not have a unified or operational framework in which to think technology. This is not surprising because, even when he writes to express his rejection of Cournot's systemic insight into the becoming of rationality, Ruyer is under the spell of this giant mathematician and statesman. Ruyer appears as conservative and somewhat reactionary in Simondon's construal, as one who rejects most of the illuministic existentialism that Simondon will manifest in his description of a sort of ersatz of the sacred in his 3 July 1969 letter (see Simondon 1992).

\section{Simondon and Ruyer on Individuation and the Latent Unity of a Cosmic Fabric}

In his major contribution to a philosophy of individuation, Simondon notes that substance and individual have been starting points for every attempt at an ontology (2005: 39-40, 48-9, 92-3). What has been overshadowed by this way of posing the question of individuation is the relational process, which makes the thing what it is and makes it different from all others. It is also an invitation to think about what could create the conditions for a substitution of the reality of the individual and, by the operational character of the process of individuation, renew the classical problem of the principle of individuation.

It is not so much an ontology that we need as an ontogenesis. If one succeeded in thinking a relationality antecedent to its terms (even if relationality already creates a substantival orientation), one would make of relation a notion that is freed from the stronghold of the traditional concept of substance. From the viewpoint of gnoseology, one would not understand knowledge as a direct link between a knowing subject and a known object, but as a relation between things constituted in their very being by relations in the process of being-related together. Therefore, Simondon searches for a thought of the mitsein, of the in-between, applied to individuals and their milieu. He will speak of 'transindividuality', as this double motion of individualisation of the individual making itself. Simondon harks back to a tradition, as Debaise observes, that wants to topple relation and substance/terms, and 
make relation the fundamental category, giving it the same status as being (Debaise 2004: 16). Deleuze has remarked that the atomists and the hylomorphists both presupposed something: the atom, the form which entered into relations.

To turn relation into being, into a definite atomic or objectual self, and to define the continuing ontic self through time by means of relation to a milieu, still leaves out the question of the persistence of a self or individual over time. When Simondon says that relation constitutes the being of an individual, he means its becoming as ontogenesis. The continuation through time is grasped by the never-ending relation with a milieu, as a relation capable of further individuations. This does not answer the question of the individual becoming different, in other words, of truly having or undergoing a genesis.

Simondon considers that the ancient atomists looked for the principle of individuation in the results of individuation and not in the operation of individualisation. Deleuze noted in Difference and Repetition that for the ancients, relations gave the impression of happening inside a time and a space (Deleuze [1968] 2004: 340). Atoms were Parmenides' 'being' pulverised, but which retained its properties. For Deleuze, one should not start the comprehension of multiplicity with a concept of unity in its multiplication, saying that the multiple is one and the one is multiple. If this programme is carried to the end, substantive reality would be multiplicity, and so difference would come to replace the dialectic of the one of the many. When multiplicity and relation are put at the centre of everything, the concept of conflict, of $\pi 0 \lambda \varepsilon \mu o \varsigma$, becomes central. As Del Lucchese points out (2009: 187), Simondon believed that the individual is created by its relation to an environment, resisting any unified flux of cosmic being. As Del Lucchese remarks again, following Muriel Combes, if one pushes this to the end, and reverses the Hegelian formulation where we do not get convertibility of real and rational, but instead of relational and substantive - 'all that is relational is real, and all that is real is relational' - one ends up with an implicit negation of the very concept of the model, with anarchies substituting themselves for representations (Del Lucchese 2009: 187; see also Combes 2013: 19).

Therefore, the opposition of Ruyer and Simondon is not a blatant one and it is not something overt. Simondon allows for an ungraspable relational yet vital power in nature, a power that is always conjugated in the present participle, a $\varphi v \sigma l \varsigma$ in the Greek sense (Simondon 2005: 92), a power that always allows for a plane of orderliness that is also a permanent potential for individuations in the plural. Like Whitehead, there are indeed tendencies or lines of trajectory establishing 
individuality as societal occasions, which by an ontological propagation have amplified themselves as occasions that then represent orders of order, or ontological hierarchical ordering in terms of a relationalcreative process. In the end, those that have accomplished a temporary unity and concresced their respective form are the only individuals who have become truly 'alive'.

Ruyer adds that there is a difference between any material realisation encountering limitation and the power of the idea or form itself, which can be expressed with very little matter in the case of informational dissemination. When, however, de Santillana responds to Ruyer's presentation and talks about the real possibility of machines coming to control human becoming after achieving self-reproduction (de Santillana 1958: 425), Ruyer ironises this proposal and, in a manner that is fairly abrupt, calls him to task for verging on the fantastic. For Ruyer, information requires a framing of human consciousnesses that no machine might ever accomplish.

If one can object to the idea of information only existing in a human consciousness, finding that it represents a misunderstanding of what information theory is all about, as in Merleau-Ponty's criticism of Ruyer (Merleau-Ponty 1995: 218-19), ${ }^{2}$ it remains that Ruyer, by insisting on this 'mentalisation' of information being different from machines, has kept his theory of informational reconstruction away from attempts at reifying the concept that human beings will always have informational shortcomings when pitted against machines (e.g. cyborgs, robots, artificially created intelligence) (see Chapouthier 2013: esp. 25-6).

\section{A Duality of Accent, or Alternative Directions in Ontology?}

What judgement would Simondon utter on the thought of Ruyer? He certainly read Ruyer's book on cybernetics referenced here (Stengers 2002: 144), and if we use his article/response on technology to make our own judgement, we find Simondon measuring his thought against that of Ruyer, as one would before an admittedly giant thinker, without uttering much direct criticism. Simondon is content with reacting to a very general stance when faced with a problem that is entangled with prospective and futuristic thinking.

What is more helpful is to reconsider Ruyer's position, expounded here with large brushstrokes and with a greater range than only considering the 1958 article on technology and its limits, while doing it in the light of Simondon's framework regarding the harmonious fusing of the human and the technological, echoing the thought of Ernst Jünger. 
Clearly, for Ruyer (and for Jünger and Simondon) the technological is aroused, or triggered, when at its end-points of contact with the material universe, it obeys an action in search of its own harmonious integration in a cycle. Simondon's emphasis then goes on to discuss the sustained powers that allow for a malleable notion of matter to be detached from any binary, purely rational analysis in terms of $\mu \rho \rho \varphi \eta$ and $\nu \lambda \eta$; his is a notion of matter that always comes to us already informed, sustaining orders upon orders of relational configuring, which strikes away from the picture a hasty reduction of the material to a domain controlled through and through from above in a top-down fashion (Simondon [1958] 1989: 74).

If one tried to frame the problem in terms of the freedom of the material universe, thought about as actual entities, to adopt configured states without mental guidance, one could certainly go in the direction of classical 'order from noise' or 'order from chance' paradigms. In these terms, Ruyer stated that 'the notion of a pure realm of fluctuations sorting themselves out is a logical contradiction of the same sort as the notion of a pure power to change, without the continuity of an object of which it would be possible to say that it changes' (Ruyer 1956: 342). Ruyer's anti-substantialism does not end up in an attempt to make relations substantial, although he shares in the dethronement of classical entelechy. The reason for it seems to be that Ruyer does not so much eliminate substantiality as resorb it in an archetypal domain, thus also making information 'form as one', something that can only come with mind-imprinted harmony.

The question that remains to be answered is whether or not this would capture a theory such as that of Simondon. Prima facie, Simondon is not trying to say that chance variations could have brought about all there is, whether its mode of organisation be lateral and accidental, or formdependent. For him, the fact that there is never an identity but a process of individualising, of realising concretisations, is also a move towards the assertion that there is more than identity to be recognised in preindividualised states, which ushers in Simondon's notion of metastability (Combes 2013: 6). This seems to give him an operator of reversion, since any theory of the power of life, unity or organisation will need to point to a reservoir of ontological 'excess' where it is definitely not in need of any higher harmonious integration. We have seen how this comes to play, and how, substituting differences for dialecticising of the one and the many, it can only offer anomy, or monstrous individuation since it is perpetually non-reduced and as such precisely potent in the sense of $\chi \propto 0 \sigma \mu \circ \varsigma$, a term often used by Deleuze. 


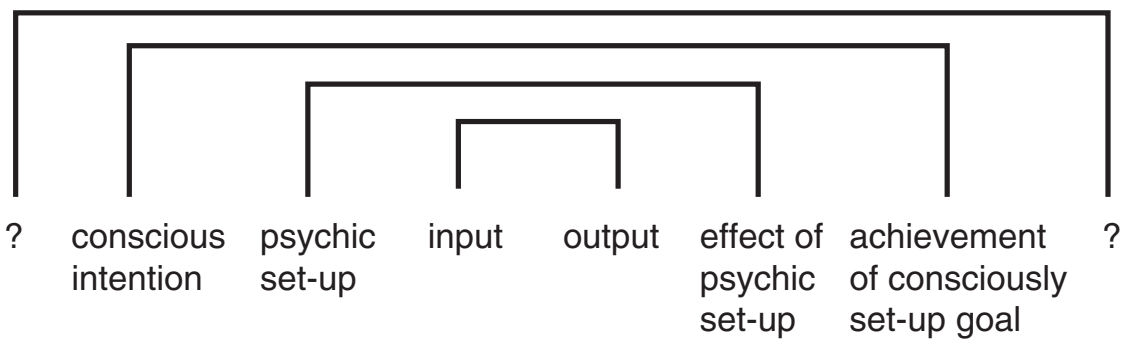

Figure 2. Chinese room/universal piloting of action. (Source: R. Ruyer, Dieu des religions, Dieu de la science, 1970, p. 114 , translated.)

The project of Simondon has a technological determinist component, true (de Vries et al. 2015: 301-2), and one wonders what in the end is the motivation of awaiting a system of the human-technological that could turn human accomplishments into some furtherance of a technological remaking of the given, as it comes to us in the (Ruyerian) form of intelligence via a 'primary consciousness'. For Ruyer the excess of this reservoir of ultimate harmonious existence would be found in the 'psychic set-up' to 'effect of psychic set-up' circuit. There alone could one find a justification of the perpetual motion of the third kind, correcting mechanistic cybernetics with an ontological-axiological verticality, which is to say, in other words, by an even more universal framing of vital development. We learn from a nature to which it costs nothing to pluralise individuality. And yet individuals are nothing but 'metaphysical zeros', as Bergson pointed out (Bergson [1907] 1911: 334), they are nothing more than a not-entirely-in-act entity chasing an existence for itself as a universal.

Simondon's position lacks a principle of dialecticisation, as everything seems to become individuation. In those terms, his ontology remains suspended to the indefinite number of configurations, that are also selfconfigurations of natura naturans, testifying to the unfinished symphony of a universe whose multifarious form-producing powers no one will ever exhaust. The oft-invoked example of the crystal is still mapped onto the Parmenidean and Euclidean morphing, and this is why Ruyer, who also considered it at length in his 1948 Le Monde des valeurs, introduces what could look like a substantification of the species at the centre of his 'universe in a parabola' diagram (see Figure 2).

What Ruyer is in fact doing is to resorb individuality in the $\varepsilon i \delta o \varsigma$, not in any abstract idea, but in end as norm. Ruyer does not give more 
reality to any embodied form of individuation, rather he insists on the suspension of any numerically differentiated individuality.

When this is replaced in the subject of his response to Ruyer, one finds Simondon siding with the enthusiasm for exploration of all undisclosed possibilities, which is also-through the promotion of relations over being - an affirmation of the value of displacement for displacement's sake. To the end of the closed world, about which A. Koyré wrote, to the setting-in of the time of the finite world (Valéry in Regards sur le monde actuel, 1945), there responds the stamina of some adventurers who, like Christopher Columbus, take as their mission to pull us out of the asthenic reduction of human-centred ontologies' self-interest. Jules Verne still stands as the most telling example of this travellingto-travel drive (Angenot 1979: 22-4), and his tales are not, contrary to a common misconception, fantastic explorations in science fiction; they are a projection ahead of the latent and tacit resources not so much of scientific inventions as of immanent intelligibility that becomes one with the universe. Typical is Verne's reaction to H. G. Wells's fictional writing on science: 'I use physics, he invents' (Dupuy 2013: 134).

For Ruyer, by way of contrast, once the impossible has been negated, one can look for another means of bridging the gap to an ultimate meaningfulness. Simondon starts his letter on orthoaesthetics with a criticism directed at an unjustified rejection of the religious (Simondon 1992: 1). It remains to be appreciated by future research if Simondon's open frontier for technological inventiveness is predicated upon the germs of a technolatry. His description of the 'gametic' aspects of the human to technical object relationship, for instance in the use of the double-headed mechanical key (6), are not only fascinating, they correct more powerfully than ever before seen the abstractive original sin of philosophers. This certainly makes him as important a cybernetic philosopher as his great ancestor, Ruyer.

For Ruyer, however, whose notion of 'anti-paradoxes' we have discussed, once the impossible has been wiped off, one can look for another means of bridging the gap to ultimate meaningfulness. Among the characteristics of our world we find two major ones which, since the industrial revolution, have gone in opposite directions. One is the importance given to the freedom of the individual person, and the other is the quest for power expressed through organised life in common, which usher in means of socialisation along with a regimentation of life. As theologian Y. Congar remarked, for all the value attached to freedom, we have seen how individuals have fallen at the mercy of the nation-state power, and to that of the industrial enterprise. Factors like competition, 
endless propaganda and aggressive publicity, educational institution and factories where a concentration of people encourages the use of mass psychology, and the intervention of the state responsible for the common good with its view to engineering it, have all tended to reduce human beings to the state of creatures of the mass. Individuals and parcelled initiatives have reacted against this, but in what form and shape? There is a risk of being torn into letting one's life be split into compartments, one for working life, for the struggle of dealing with material existence, and the other for leisure, with counterbalance time which is used to try to tone up one's nerves (Congar 1960). Ruyer himself, faced with this very problem in his critical review of Stent, does not really offer another answer than that of maximising one of the terms of the alternative: pace Cournot's philosophising on the rise of mechanised planning, we are inventing silently the means of a reinvestment of the ludic (Ruyer 1975; see also Gagnon 2014). The first stage of the industrial revolution brought a new world of slaves serving machines, of depersonalised individuals without cultural background. Then, there was a reaction when educated people tried to gain a personal culture enabling them to live more easily the life of the mind. If, however, the machine sets men free from the necessity of toil, automation will increase this trend and there will be, as Freud stoically admitted in Civilization and Its Discontent, the question of having freed more time, but 'to do exactly what?'

A Spinozist ontology reabsorbs the mysterious aspect of God and collapses it in the immanent and manifested. In L'Embryogenèse $d u$ monde, Ruyer insists on the presence of undisclosed possibilities (Ruyer 2013: 162-4), yet he does not want for an irrational exploration of possibilities. What this means is that if we realised the absorption of the universe in the human piloting agent, as many versions of the cyberworld have dreamt of, we could perhaps get a universe remade in our image, but again, what would we act for? Ruyer contemplated this situation, when he pointed out clearly that for humans to be made facies totius universi, with the universe remade in human traits, would usher us into that situation theatrically portrayed in Also sprach Zarathustra: an overcoming of what it has meant to be human. We know the invectives directed at those who claim that their status of letzte Mensch, of the highest fruit of cosmic becoming, places them at the pinnacle: they have not invented the new tables of value (Nietzsche 1974: 47). Similarly for Ruyer, in this situation, the whole universe, even if it acquired our beating heart through some concretisation of the kind contemplated by Simondon, would leave us suspended, depending 
on meaning and its unending adventurous exploration (Ruyer 1953: 262). This is not adventure in Verne's sense, it is not exploration for exploration's sake, rather it signals the attainment of a view to the monde fini, the finite world as in Valery's aphorism, which alone makes possible the recognition of God as utterly Other, as the Source and End of meaning and values.

Ruyer rejects any interpretation of freedom that succumbs to rational technocracy. He wants individuals to think about a volitional void or potency that is immediately 'plenitudised', filled with the strenuous character of meaning (sens), which takes over from physical laws, and allows in return to look back at those and see that, all along, they were obeying what is in fact a norm. In the last retrenchment of his metaphysical work, Ruyer has displaced the rationalist conviction of epistemology which would orient the work of scientific thinking towards the pursuit of intelligibility. His is not a philosophy of intelligibility, placing in the knower the ultimate $\alpha \tau \alpha \rho \alpha \chi l \alpha$ which comes with the reestablishing of technical information. Intelligibility surely puts the mind to rest, but would furnish nothing that could account for its perdurance as ontogenetic dynamism. It would merely furnish an abstract scheme, but nothing which could even remotely account for the experience that is dynamic consciousness, a process that 'goes over the edges' of the scattered points of mechanism. It is less intelligibility that prospective thinking pursues than meaning. This assures us that there will always be a horizon beyond, and it is why the reservoir of all the possibles which will be named God through much apophatism cannot present itself as an end in itself, as a Person in the Kantian sense, but has to present itself as vital potency or at best ontogenetic dynamical vital conditions. This ontological norm presents the problem, as discussed, that perhaps there is nothing more abstract than the conditions implied to generate what is abstract. Precisely, for whoever has mapped out Ruyer's idiosyncratic inversion, an abstract that informs the actual is not abstract, since it is perpetually filled by the desire of beings in their quest to achieve abstract form, true beings who pursue the always-yet-to-be-fulfilled universal nature of that form.

\section{Notes}

1. The Belgian mathematician, astronomer and demographer (who lived from 1796 to 1874), was the first to break a trend in using statistics in a moral way, using the norm as he saw it to regulate, and thus to 'feed back' into social becoming.

2. Ruyer observed: 'la connaissance, qu'elle vise le tout ou les parties, ne peut être sans base d'information, autrement, elle ne serait pas une connaissance.-... 
knowledge, aiming at the whole or the parts, cannot be without an informational basis, since otherwise it would not be knowledge' (Ruyer 1963: 18). In another article, Ruyer admits that some bonds are real even in heaps (Ruyer 1970b: 125).

\section{References}

Angenot, Marc (1979) 'Jules Verne: The Last Happy Utopianist', in Patrick Parrinder (ed.), Science Fiction: A Critical Guide, London and New York: Longman, pp. 18-33.

Bergson, Henri [1907] (1911) Creative Evolution, trans. A. Mitchell, London: Macmillan.

Chapouthier, Georges (2013) 'Information, structure et forme dans la pensée de Raymond Ruyer', Revue philosophique, 138:5, pp. 21-8.

Combes, Muriel (2013) Gilbert Simondon and the Philosophy of the Transindividual, trans. T. LaMarre, Cambridge, MA: MIT Press.

Congar, Yves-Marie (1960) 'Holy Spirit and Spirit of Freedom', in Laity, Church, and World, trans. D. Attwater, Baltimore: Helicon Press, pp. 1-34.

Cournot, Antoine Augustin (1861) Traité de l'enchaînement des idées fondamentales dans les sciences et dans l'histoire, Paris: Hachette.

Cournot, Antoine Augustin (1875) Matérialisme, vitalisme, rationalisme, Paris: Hachette.

Debaise, Didier (2004) 'Qu'est-ce qu'une pensée relationnelle?', Multitudes, 18:4, pp. 15-23.

Deleuze, Gilles [1968] (2004) Difference and Repetition, trans. P. Patton, London and New York: Continuum.

Del Lucchese, Filippo (2009) 'Monstrous Individuations: Deleuze, Simondon, and Relational Ontology', Differences, 20:2-3, pp. 179-93.

de Santillana, Giorgio (1958) 'Note sur l'article de M. Ruyer', Revue de métaphysique et de morale, 63:4, pp. 423-6.

de Vries, Marc, Andrew Feenberg, Arne De Boever and Aud Sissel Hoel (2015) 'Book Symposium on the Philosophy of Simondon', Philosophy \& Technology, 28:2, pp. 297-322.

Dupuy, Lionel (2013) 'Les Voyages extraordinaires de Jules Verne ou le roman géographique au XIX ${ }^{\mathrm{e}}$ siècle', Annales de géographie, 690, pp. 131-50.

Gagnon, Philippe (2014) 'Le paradoxe du progrès: Cournot, Stent et Ruyer', in Michel Weber and Vincent Berne (eds), Chromatikon X: Yearbook of Philosophy in Process, Louvain-la-Neuve: Éditions Chromatika, pp. 71-90.

Hutchinson, Ian (2000) 'Faith in the Machine', Perspectives on Science and Christian Faith, 52:4, pp. 260-2.

Jünger, Ernst (1994) Le Mur du temps (1959), trans. H. Thomas, Paris: Gallimard.

Kurzweil, Ray (1998) The Age of Spiritual Machines, New York: Penguin.

Liard, Louis (1877) 'Un géomètre philosophe-Antoine-Augustin Cournot', Revue des Deux Mondes, 22, pp. 102-24.

Merleau-Ponty, Maurice (1995) 'Le concept de nature 1957-58', in La Nature. Cours du Collège de France, ed. D. Séglard, Paris: Seuil.

Nietzsche, Friedrich (1974) Thus Spoke Zarathustra, trans. R. Hollingdale, Harmondsworth: Penguin.

Quetelet, Adolphe (2013) A Treatise on Man and the Development of His Faculties, trans. R. Knox, Cambridge: Cambridge University Press.

Ruyer, Raymond (1930) L'humanité de l'avenir d'après Cournot, Paris: Alcan.

Ruyer, Raymond (1953) 'Expériences mentales sur la mort et la vie', Revue de métaphysique et de morale, 58:3, pp. 237-63. 
Ruyer, Raymond (1956) 'Les postulats du sélectionnisme', Revue philosophique, 156, pp. 318-53.

Ruyer, Raymond (1958) 'Les limites du progrès humain', Revue de métaphysique et de morale, 63:4, pp. 412-27.

Ruyer, Raymond (1963) 'La science et la philosophie considérées comme des traductions', Les Études philosophiques, 18:1, pp. 13-20.

Ruyer, Raymond (1968) La cybernétique et l'origine de l'information, 2nd edn, Paris: Flammarion.

Ruyer, Raymond (1970a) Dieu des religions, Dieu de la science, Paris: Flammarion.

Ruyer, Raymond (1970b) 'Le petit chat est-il mort? Ou trois types d'idéalisme', Revue philosophique, 160, pp. 121-34.

Ruyer, Raymond (1975) 'Les limites du progrès', Contrepoint, 16, pp. 123-33.

Ruyer, Raymond (2013) L'embryogenèse du monde et le Dieu silencieux, Paris: Klincksieck.

Shapiro, Kevin (2005) 'This Is Your Brain on Nanobots', Commentary, 1 December, pp. 64-8.

Simondon, Gilbert (1959) 'Les limites du progrès humain', Revue de métaphysique et de morale, 64:3, pp. 370-6.

Simondon, Gilbert [1958] (1989) Du mode d'existence des objets techniques, Paris: Aubier.

Simondon, Gilbert (1992) 'Sur la techno-esthétique et réflexions préalables à une refonte de l'enseignement', Papiers du Collège international de philosophie, 12, pp. 1-19.

Simondon, Gilbert (2005) L'individuation à la lumière des notions de forme et d'information, Grenoble: J. Millon. [This monograph makes available together the two parts of Simondon's doctoral dissertation, which were previously published separately, the first as L'individu et sa genèse physico-biologique (Presses universitaires de France, 1964) and the second as L'individuation psychique et collective (Aubier, 1989).]

Simondon, Gilbert (2010) 'The Limits of Human Progress: A Critical Study', trans. S. Cubitt, Cultural Politics, 6:2, pp. 229-36 [translation of Simondon 1959].

Stengers, Isabelle (2002) 'Pour une mise à l'aventure de la transduction', in Pascal Chabot (ed.), Simondon, Paris: Vrin, pp. 137-60.

Whitehead, Alfred North [1929] (1958) The Function of Reason, Boston: Beacon Press. 